\title{
Strategi Adaptasi: Kisah Desa Kawa dan Desa Morodemak dalam Menghadapi Perubahan Populasi dan Ekologi
}

\author{
Adaptation Strategies: Tales From Kawa Village and Morodemak Village \\ in Facing Population and Ecological Changes
}

\author{
Widhyanto Muttaqien $^{1 *}$ \\ ${ }^{1}$ Pusat Pengkajian Perencanaan dan Pengembangan Wilayah (P4W) LPPM - Institut Pertanian Bogor, \\ Jalan Raya Pajajaran, Kampus IPB Baranangsiang, Bogor 16127, Indonesia; \\ *Penulis korespondensi.e-mail: red.sinau@gmail.com \\ (Diterima: 22 Februari 2018; Disetujui: 11 Mei 2018)
}

\begin{abstract}
Population growth in coastal areas, especially as a result of migration, has put pressure on the environment, both the built environment and the community management environment in implementing sustainable livelihood strategies. This paper wishes to explain two models of community adaptation in two distinct areas, namely Morodemak Village on the north coast of Central Java, which began to recede in the management of common resources, and Kawa Village in Seram Barat coast, which is still strong in maintaining the tradition of coastal and terrestrial territorial management as a common resource. The research methodology used in this research is qualitative approach, with semi structured interview and focus group discussion. From the results of the study, it was revealed that people were able to reshape their resources based on ecological and social changes, as their adaptation strategy in sustaining sustainable livelihoods.
\end{abstract}

Keywords: adaptation strategy, ecological change, migration pattern, sustainable livelihood

\begin{abstract}
ABSTRAK
Pertumbuhan penduduk di wilayah pesisir, terutama sebagai akibat dari migrasi, telah memberi tekanan pada lingkungan, baik lingkungan binaan maupun lingkungan pengelolaan masyarakat dalam menerapkan strategi penghidupan yang berkelanjutan. Makalah ini ingin menjelaskan dua model adaptasi masyarakat di dua wilayah berbeda, yaitu Desa Morodemak di pantai utara Jawa Tengah yang mulai surut dalam pengelolaan sumber daya bersama, dan Desa Kawa di pantai Seram Barat yang masih kuat dalam mempertahankan tradisi pengelolaan wilayah pesisir dan terestrial sebagai sumber daya umum. Metodologi penelitian yang digunakan dalam penelitian ini adalah pendekatan kualitatif, dengan wawancara semi terstruktur dan diskusi kelompok terarah. Dari hasil penelitian terungkap bahwa orang mampu membentuk kembali sumber daya mereka berdasarkan perubahan ekologi dan sosial, sebagai strategi adaptasi mereka dalam mempertahankan mata pencaharian yang berkelanjutan.
\end{abstract}

Kata kunci: perubahan ekologi, pola migrasi, strategi adaptasi, sumberdaya bersama penghidupan berkelanjutan 


\section{PENDAHULUAN}

\section{Permasalahan}

Persoalan keterbatasan lahan dan penyusutan sumber daya alam merupakan faktor pendorong dalam perubahan mata pencaharian dan penghidupan berkelanjutan di kawasan pesisir. Perubahan ini mendorong pada perubahan lainnya, yaitu pola-pola migrasi, serta adaptasi terhadap perubahan lanskap sosialbudaya. Sementara potret umum masyarakat nelayan adalah kemiskinan (Nurcahyanti et al., 2010) dan kekumuhan dalam permukiman (Haryono, 2007; Kusnadi, 2000).

Dalam konteks eksploitasi sumber daya perikanan, nelayan memiliki perilaku sebagai berikut; (1) mengeksploitasi terus-menerus sumber daya perikanan tanpa memahami batasbatasnya; (2) mengeksploitasi sumber daya perikanan, disertai dengan merusak ekosistem pesisir dan laut, seperti menebangi hutan bakau serta mengambil terumbu karang dan pasir laut, kurangnya pengetahuan (Woodward and ColinCastilo, 2015; D.S. Adhuri et.al., 2016); (3) mengeksploitasi sumber daya perikanan dengan cara-cara yang merusak (destructive fishing), seperti kelompok nelayan yang melakukan pemboman ikan, melarutkan potasium sianida, dan mengoperasikan jaring yang merusak lingkungan, seperti trawl atau minitrawl; serta (4) mengeksploitasi sumber daya perikanan dipadukan dengan tindakan konservasi, seperti nelayan-nelayan yang melakukan penangkapan disertai dengan kebijakan pelestarian terumbu karang, hutan bakau, dan mengoperasikan jaring yang ramah lingkungan (Kusnadi, 2009).

Perubahan ekologi di Desa Morodemak, dimulai dengan program tambak rakyat, yaitu bandeng dan udang sekitar tahun 1980. Tren konversi lahan dari kawasan lindung berupa hutan bakau menjadi tambak terus meningkat seiring keuntungan finansial yang diberikan oleh

\footnotetext{
${ }^{1}$ Potensi konflik di Maluku telah berlangsung lama, sejak jaman Belanda, dimana masyarakat Maluku yang mayoritas Kristen mendapatkan privelese dari pemerintah Belanda dalam administrasi dan kependudukan, dan tiba-tiba terjadi perubahan sejak jaman Orde Baru, sehingga menimbulkan rasa tidak nyaman dan rentan dengan perubahan populasi.
}

usaha tambak, sampai terjadi penurunan produksi yang diakibatkan oleh penyakit pada udang dan bandeng, yang menurut masyarakat disebabkan oleh 'air kotor' yang diperkirakan disebabkan karena deforestasi bakau dan sampah domestik yang memengaruhi kualitas air untuk tambak. Deforestasi kawasan Mangrove disebabkan oleh penggunaan batang bakau untuk kayu bakar.

Kawasan bakau yang menjadi habitat kepiting lumpur (Scylla serrata) yang dianggap hama bagi petambak. Kepiting ini merugikan karena merusak pematang tambak sehingga menyebabkan kebocoran-kebocoran pada dinding tambak akibat lubang yang dibuatnya. Kebocoran tersebut dapat menyebabkan lepasnya bandeng melalui lubang tersebut.

Sekitar tahun 2000-an, masyarakat mulai disadarkan dengan kondisi ini dan mulai melakukan penanaman kembali hutan Mangrove mereka. Hasilnya, menurut masyarakat telah dirasakan dengan membaiknya kembali usaha tambak bandeng dan udang, serta munculnya rajungan dan kepiting dalam jumlah cukup banyak.

Perubahan lanskap ekologi di kawasan Desa Kawa tidak berjalan masif. Hal ini disebabkan masih terjaganya status Kenegerian Kawa sebagai pemangku adat yang mengelola wilayah adat Negeri Kawa. Secara adat suku asal disebut sebagai 'orang adat' dan pendatang disebut 'penghuni adat'. Para pendatang diperbolehkan memiliki lahan dan mengusahakan permukiman dan perkebunan, namun kepemilikan lahan dibatasi setelah peristiwa konflik agama tahun 1999 hingga 2007. Dalam Kanas et al., (2017) $)^{1}$ disebutkan bahwa dalam konflik Ambon rasa tidak aman akan kehilangan pekerjaan karena kehadiran kelompok lain di luar kelompoknya. Kekhawatiran lainnya adalah hilangnya kebiasaan, adat, dan tradisi ketika kelompok lain

Rasa tidak aman ini sebagai ancaman tak nyata menjadi nyata ketika pemerintahan Orde baru berakhir tahun 1998 dan masing-masing kelompok terus membangun persepsi negatif terhadap kelompok lainnya. 
mendominasi. Ini terjadi dalam relasi di dalam kelompok maupun antar kelompok.

Sedangkan orang adat masih memiliki wilayah kelola adat yang terbagi atas kepemilikan bersama (common property) dengan pembagian berdasarkan marga, kepemilikan pribadi (private property) dan kepemilikan negara (state property). Raja Negeri Kawa menilai beberapa kawasan lindung yang ada termasuk sebagian hutan Mangrove adalah milik negara.

Perubahan ekologi di Desa Kawa, terkait komoditas yang ditanam dimulai dari maraknya tanaman coklat yang mengganti kebun kelapa dan kebun campur yang terdiri dari jeruk kunci, kelapa, rambutan, mangga, durian, cengkeh, kopi, cempedak, nangka. Komoditas coklat diperkenalkan lebih banyak oleh pendatang dari Buton, dengan pola tanam dalam satu hamparan.

Sementara orang adat menanam coklat dalam kebun campur mereka. Hanya cengkeh yang ditanam dalam satu hamparan. Orang adat masih mempertahankan dusun sagu (hutan sagu) mereka.

Penelitian ini ingin melihat bagaimana model adaptasi di dua tempat, khususnya nelayan dalam menghadapi tekanan perubahan ekologi dan pertambahan populasi.

\section{LATAR TEORI DAN METODOLOGI}

Berbagai teori tentang kemiskinan melihat masyarakat nelayan sebagai masyarakat yang rentan dengan perubahan kondisi alam, baik dalam cadangan (stock, provision) maupun dalam aliran dan distribusi pemanfaatannya (flow). Dalam Ostrom (2006) disebutkan masalah pengguna (appropriator) dalam sumber daya bersama (common pool resources) adalah pemanfaatan yang paling efisien antarpengguna. Masalah ini dipengaruhi oleh (1) eksternalitas penggunaan, yaitu relasi produksi antar-pengguna, artinya jika salah satu pengguna memaksimalkan produksinya (dalam penangkapan) maka pengguna lain akan kehilangan kesempatan yang sama; (2) permasalahan lokasi, dalam konteks spasial sumber daya bersama memiliki 'tempat' atau 'petak/kantong' (patch), 'lokasi' potensi sumber daya yang berbeda. Ada daerah penangkapan yang banyak ikannya, ada yang tidak, hal ini menimbulkan permasalahan penempatan (assignment problem); (3) ekternalitas teknologi yaitu penggunaan teknologi penangkapan yang homogen akan menimbulkan kesempatan yang sama pada setiap nelayan, sebaliknya penggunaan teknologi yang berbeda akan meningkatkan biaya pada nelayan lainnya atau pada nelayan pengguna teknologi tersebut.

Kedua, masalah pencadangan yaitu permasalahan bagaimana sumber daya dalam konteks penawaran dan permintaan dilangsungkan. Dalam sisi penawaran maka bagaimana produksi sumber daya dihasilkan dan dirawat. Sedangkan dari sisi permintaan bagaimana sumber daya dimanfaatkan, berapa kapasitas produksi yang menguntungkan atau mengapa orang berkecenderungan memaksimalkan "nilai sekarang" (net present value).

Dalam tulisan ini, penekanan terhadap sumber daya bersama di kedua desa, menjadi titik perhatian yang memengaruhi proses adaptasi dan penemuan kembali wilayahwilayah (domain) baru dalam pengelolaan sumber daya bersama.

Di sisi lain Fabinyi (2018) menjelaskan bahwa permasalahan pemanfaatan sumber daya alam juga berhubungan dengan apa yang perebutan ruang lewat teknologi. Dengan meminjam teori spatio temporal fixity, Fabinyi menjelaskan bahwa dominasi teknologi dapat 'memperluas geografi' dan memenangkan persaingan lewat alat produksi. Mengambil contoh di Mindoro, Filipina, tesis Fabinyi bersesuaian dengan apa yang dimaksud Harvey (1989, 2010) sebagai ekspansi geografis dari surplus kapital, dalam konteks ini Fabinyi melihat para pemodal telah berhasil melakukan ekspansi lewat program aquaculture melalui intensifikasi perikanan, sementara masyarakat sekitar malah meninggalkan basis pertanian dan bermigrasi keluar (out migration).

Untuk mengatasi keterbatasan dan penyusutan sumber daya, nelayan beradaptasi sesuai dengan kondisi sosial, seperti pengaturan 
sosial, pengaturan pemanfaatan sumber daya dan kondisi biofisik serta perubahan lanskap ekologi mereka. Pengaturan sosial sangat bergantung pada karakteristik budaya masyarakat bersangkutan yang melekat dalam tubuh sosial dan individu sebagai strategi penyintasan (Hardesty, 1977).

Dari sisi antropologi ekologi, adaptasi didefinisikan sebagai suatu strategi yang digunakan oleh manusia dalam masa hidupnya untuk mengantisipasi perubahan lingkungan baik fisik maupun sosial (Alland Jr, 1975). Sedangkan Sahlin (1968) memandang adaptasi sebagai kapasitas manusia untuk memaksimalkan kesempatan hidupnya. Lewat kemampuannya memodifikasi norma sosial, politik, kebiasaan untuk melakukan antisipasi, pengurangan risiko, memanfaatkan peluang yang ada, menyesuaikan diri terhadap perubahan, memitigasi potensi bencana, dan berdaya pulih (McCarthy et al., 2001; (Magis, 2010).

Strategi adaptasi berkembang ke arah manusia sebagai subjek yang mampu mengoptimalkan asetnya untuk menjawab kekurangan analisa terhadap masalah kemiskinan dan pembangunan serta intervensi sosial yang dibutuhkan.

Pendekatan penghidupan berkelanjutan merupakan salah satu strategi adaptasi yang menghubungkan individu dengan asetnya, yang dikenal sebagai pentagon aset, yaitu aset manusia, sosial, ekonomi, fisik, dan alam. Kelima aset ini menciptakan keberlanjutan ekologi, ekonomi, sosial, dan kelembagaan (Ashley \& Carney, 1999). Ellis, (2000) menghubungkan pentagon aset ini dengan karakteristik sistem nafkah di daerah perdesaan yang dibagi menjadi tiga, yaitu (1) berbasis pendapatan pertanian milik sendiri (farm income); (2) pekerjaan yang berhubungan dengan kegiatan pertanian bukan milik sendiri (off farm income) seperti buruh tani pada saat panen komoditas tertentu; (3) Pendapatan berbasis bukan pertanian (non farm income) seperti menukang, perdagangan umum, remiten dari tenaga kerja Indonesia di luar negeri, dan lain-lain.
Diagram Pentagon Asset dibentuk melalui beberapa tahapan. (1) mencari kategori aset yang penting bagi kehidupan masyarakat yang bersangkutan; (2) menyesuaikan kategori aset menurut masyarakat dengan pentagon aset dalam teori; (3) melakukan penilaian partisipatif terhadap kepemilikan aset berdasarkan status ekonomi dan sosial atau kelas sosial; (4) mengolah hasil penilaian ke dalam bentuk grafik; (5) mempresentasikan hasil dalam bentuk grafik kepada masyarakat untuk memperkaya narasi.

Penelitian ini merupakan sebagian dari penelitian riset aksi tentang perbaikan perkampungan nelayan di 10 Provinsi. Pemilihan lokasi pada tulisan ini dibatasi dua lokasi dengan argumentasi untuk memperlihatkan distingsi pemanfaatan sumber daya berbasis sumber daya bersama dengan sumber daya privat.

Tulisan ini menggunakan metode pengambilan data dengan wawancara semi terstruktur dan diskusi terarah. Wawancara semi terstruktur dilakukan dengan metode triangulasi responden yang membagi responden berdasarkan tingkat kemiskinan. Jumlah responden untuk wawancara ada 15 orang di tiap desa. Pemilihan responden menggunakan informasi dari informan. Untuk Desa Kawa informannya adalah Kepala Adat, dan perwakilan penghuni adat dari suku Buton. Sedangkan untuk Desa Morodemak yang berlaku sebagai informan adalah 3 orang tokoh masyarakat yang dianggap mengetahui seluk beluk sejarah desa.

Sedangkan jumlah peserta untuk diskusi terarah sebanyak 30 orang di tiap desa berdasarkan kategori pemanfaat sumber daya dan gender. Lama waktu penelitian di tiap desa satu minggu. Dilanjutkan dengan wawancara lewat telepon kepada beberapa informan untuk verifikasi data.

\section{Profil Desa Kawa}

Desa Kawa (dikenal dengan sebutan Kenegerian Kawa, dengan kepala adat yang disebut Raja) merupakan salah satu Desa di kecamatan Seram Bagian Barat, Kabupaten 
Seram Bagian Barat, Provinsi Maluku. Jarak Dusun Kawa dengan Ibukota Kabupaten Seram Bagian Barat $\pm 30 \mathrm{~km}$. Secara administratif Desa Kawa berbatasan di bagian utara dengan Laut Seram, bagian selatan dengan Teluk Piru, bagian timur dengan Dusun Pelita Jaya, dan bagian barat dengan Selat Buano.

Desa Kawa memiliki kontour datar dengan pantai yang beragam, mulai dari pantai berbatu dan curam, sampai pantai yang berhutan Mangrove. Hutan Mangrove sebagai vegetasi tepi pantai masih baik kondisinya di dusun ini. Disamping ini juga dijumpai beberapa tanaman produksi terutama berbentuk pohon di halaman mereka seperti kelapa dan beberapa pohon buah lokal.

Kebun campur masyarakat terdapat di luar wilayah permukiman, yang dimiliki oleh orang adat dan penghuni adat. Orang adat masih memiliki dusun sagu.

Di Negeri Kawa terdapat 5 dusun yaitu Kawa, Waeyoho, Pohon Batu, Patinea, dan Waetoso dengan pusat desa berada di Kawa. Dusun dengan kondisi seratus persen adalah nelayan yaitu Waeyoho dan Pohon Batu. Dusun Kawa sebagian besar merupakan petani sedangkan jumlah nelayannya lebih sedikit dari dusun Waeyoho dan Pohon Batu. Dusun Patinea meskipun berada di wilayah Negeri Kawa tetapi secara adat bukan bagian Negeri Kawa karena merupakan masyarakat yang bermigrasi dari negeri lain. Dusun Waetoso merupakan dusun termuda yang berpenduduk sebagai petani sawah beretnis Jawa melalui program transmigrasi.

Jumlah rumah tangga perikanan (RTP) dan jumlah nelayan di Dusun Kawa dapat dilihat pada tabel di bawah ini.

Tabel 1. Jumlah penduduk di Desa Kawa

\begin{tabular}{|c|c|c|c|c|}
\hline No & $\begin{array}{l}\text { Kriteria } \\
\text { Penduduk }\end{array}$ & Jumlah & \multicolumn{2}{|c|}{ Jumlah Penduduk } \\
\hline 1. & $\begin{array}{l}\text { Total } \\
\text { Penduduk }\end{array}$ & Jumlah & 2,090 & Jiwa \\
\hline 2. & Kepala Kelua & rga & 530 & KK \\
\hline 3. & $\begin{array}{l}\text { Rumah } \\
\text { Perikanan }\end{array}$ & Tangga & 215 & RTP \\
\hline 4. & $\begin{array}{l}\text { Jenis } \\
\text { Pencaharian } \\
\text { (Nelayan) }\end{array}$ & Mata & 180 & Jiwa \\
\hline
\end{tabular}

\section{Profil Nelayan}

Dusun Kawa memiliki jumlah nelayan yang lebih sedikit dibandingkan dusun lain, terutama dusun Waeyoho dan Pohon Batu, yang merupakan pendatang dari Buton. Dusun Kawa dihuni oleh Orang Adat (suku asli) sementara dusun Waeyoho dan Pohon Batu dihuni oleh nelayan dari Buton. Dalam Adhuri (2016) tiga suku Buton, Bugis, Makassar (dikenal dengan singkatan BBM) adalah kelompok-kelompok nelayan yang mobilitasnya tertinggi di kawasan Timur Indonesia dan memiliki tingkat penerimaan cukup tinggi di kalangan penduduk asli.

Di Kawa dan Waeyoho untuk pemasaran hasil perikanan, terdapat pengumpul ikan. Khusus untuk Waeyoho selain memasarkan hasil tangkapan melalui pengumpul di dusun, mereka juga sering langsung memasarkan hasil tangkapan di Ambon. Sebagian besar tangkapan nelayan Waeyoho adalah komoditas ekspor Korea dan Jepang. Nelayan di Pohon Batu umumnya nelayan teri yang menjual teri segar dan kering kepada pengumpul di Pulau Osi untuk dijual kembali di Surabaya.

Sasi laut merupakan aturan adat dari Etnis Kawa yang memanjang dari Waeyoho sampai Kawa. Aturan ini dibuat untuk melestarikan ikan di laut. Diberlakukan larangan menangkap ikan pada radius 100 hingga $400 \mathrm{~m}$ dari pesisir dalam kurun 1 sampai 2 tahun sampai sasi dibuka. Tujuanya untuk membiarkan ikan-ikan berkembang terlebih dahulu agar hasil tangkapan tetap banyak. Apabila melanggar maka akan dikenakan denda. Sasi laut dibuka hanya selama 1 bulan. Waktu sasi laut ditentukan atas persetujuan raja.

\section{Sumber nafkah dan Diversifikasi Usaha}

Sumber nafkah dan diversifikasi usaha telah dilaksanakan oleh nelayan di Dusun Kawa yang umumnya masih bersifat usaha skala rumah tangga yang kegiatan usahanya hanya melibatkan anggota keluarga maupun tetangga di lingkup Dusun Kawa. 
Kegiatan on farm terdiri dari penangkapan ikan, udang, dan kepiting. Sedangkan kegiatan off farm meliputi (1) kegiatan diversifikasi loin ikan tuna dan kegiatan diversifikasi ikan asap (2) buruh petik saat panen cengkeh di Desa Kawa dan desa-desa sekitar Kecamatan Piru. Sedangkan kegiatan non farm di Desa Kawa meliputi perdagangan, buruh bangunan, sopir angkutan umum.
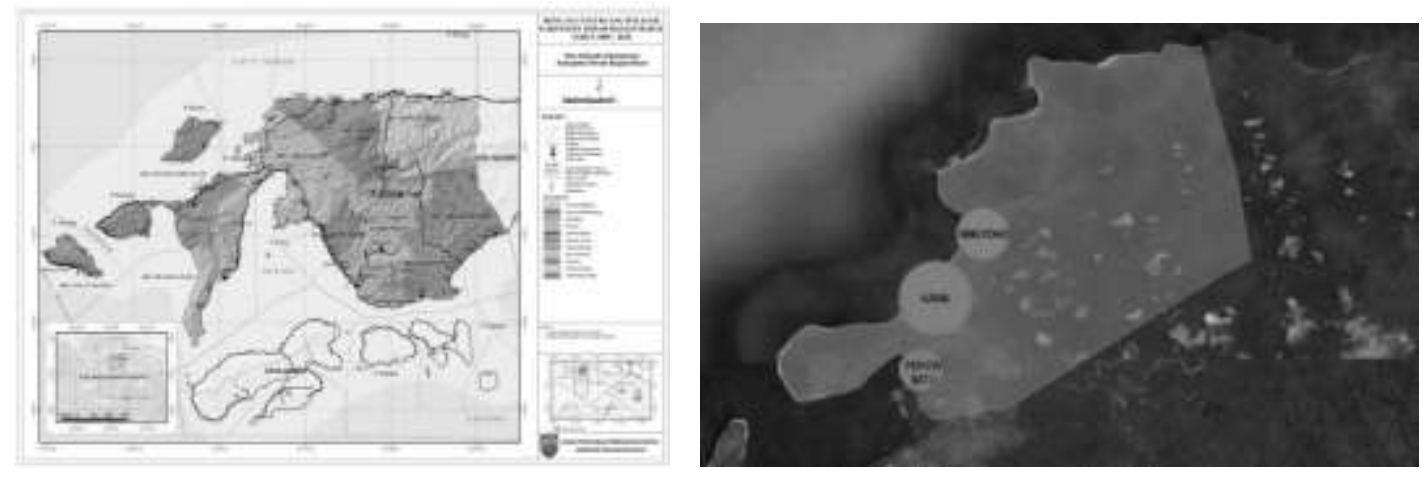

Peta 1. Lokasi kajian Desa Kawa

\section{Desa Morodemak}

Posisi geografis desa Morodemak berada pada 110032'40" BT dan 6049'30" LS. Wilayah Tri Desa Morodemak berada di wilayah muara Sungai Tuntang, terdiri dari areal pertambakan serta areal hijau berupa hutan Mangrove.

Hutan Mangrove sebagai sabuk hijau yang membatasi wilayah permukiman dan tambak mulai ditanam kembali tahun 2000-an dalam kondisi cukup baik. Pertambahan penduduk telah mengurangi luasan hutan Mangrove utuk permukiman dan tambak.

Kondisi permukiman sangat padat, hampir tidak ada pohon besar di wilayah ini kecuali di pinggir anak Sungai Tuntang. Di desa sekitarnya, Margolinduk dan Purworejo.
Sungai Tuntang mengalami pendangkalan sehingga aliran anak sungai dari permukiman warga terhambat dan rob atau air pasang menjadi bencana banjir bulanan.

Berdasarkan aspek sejarah, Desa Morodemak (428,362 ha) merupakan cikal bakal dari pengembangan desa yang berkembang menjadi Desa Margolinduk (85.94 ha) dan Desa Purworejo (840 ha). Ketiga desa tersebut disebut sebagai Tri Desa Morodemak. Konektivitas tiga desa tersebut terutama disatukan oleh kegiatan perikanan yang sejak dulu kala mereka lakukan secara bersama-sama di wilayah muara Sungai Tuntang.

Jumlah penduduk di Tri Desa Morodemak pada tahun 2013 yaitu 21,992 jiwa dengan rincian jumlah penduduk laki-laki 10,864 jiwa dan penduduk perempuan 11,128 jiwa.

Tabel 2. Jumlah penduduk Tri Desa Morodemak 2013

\begin{tabular}{llll}
\hline Desa & Penduduk & & \\
& Laki-Laki (Jiwa) & Perempuan (Jiwa) & Jumlah (Jiwa) \\
\hline Morodemak & 3,509 & 3,579 & 7,088 \\
Margolinduk & 2,475 & 2,758 & 5,233 \\
Purworejo & 4,880 & 4,791 & 9,671 \\
Total Penduduk & 10,864 & 11,128 & 21,992 \\
\hline
\end{tabular}

\section{Profil Nelayan}

Sebagian besar penduduk Tri Desa Morodemak berprofesi sebagai nelayan tradisional dengan trip one day fishing (bolak balik dalam satu hari). Terdapat dua tipe nelayan di Morodemak yaitu nelayan murni dan nelayan ikutan (ABK). Selain nelayan, masyarakat setempat banyak yang berprofesi sebagai penambak. Hanya sebagian kecil yang berprofesi sebagai pegawai dan pedagang. 
Status kepemilikan sarana penangkapan ikan milik pribadi dengan ukuran kapal rata- rata 20 GT dengan alat tangkap kursin dan cakalang. Hampir semua nelayan memiliki kapal motor tempel sendiri dan memiliki dimensi kapal yang relatif menengah hingga besar. Terdapat pembagian kerja yang melibatkan pekerja dari wilayah Tri Desa Morodemak hingga desa tetangga.

Berdasarkan wawancara, terdapat desa yang warganya berprofresi sebagai ABK. Desa tersebut adalah Desa Gebang yang berbatasan dengan Desa Margolinduk (Tri Desa Morodemak). Biasanya trip penangkapan ikan dilakukan satu kali sehari dengan 2 kali kegiatan melaut yaitu pada dini hari melakukan pemasangan bubu/jaring insang (setting) dan pada sore hari melakukan pengambilan hasil tangkapan (hauling). Adapun jenis hasil tangkapan dominan adalah teri, kembung, petek, kuningan, dan layur. Terdapat juga kepiting, bandeng, dan udang. Aktivitas perikanan tetap melibatkan (Pelabuhan Perikanan Pantai) Morodemak sebagai sentra perdagangan. Tri Desa Morodemak tetap memiliki ikatan yang erat dengan desa-desa nelayan lain di luar wilayah mereka.

Konflik yang terjadi di Desa Morodemak adalah konflik penggunaan alat tangkap. Konflik horizontal terjadi antar masyarakat yang menggunakan alat tangkap sero dengan bagan, dan alat tangkap pancing dengan arid (jaring pukat). Sedangkan konflik vertikal terjadi antara masyarakat dengan pemerintah daerah yang mengikuti aturan Peraturan Kelautan dan Perikanan Nomor 02/PERMEN-KP/2015 tentang Larangan Penggunaan Alat Penangkapan Ikan Pukat Hela (Trawls) dan Pukat Tarik (Seine Nets). Sebagian besar pengusaha pukat yang juga berkonflik dengan nelayan miskin, berdalih kelebihan penangkapan tidak bisa cuma diatur untuk mereka, sedangkan pencurian ikan oleh nelayan asing dan negara dari wilayah lain (Tegal dan Indramayu) terus menerus terjadi di depan mata mereka.

\section{Sumber Nafkah dan Diversifikasi Usaha}

Diversifikasi usaha nelayan di bidang on farm selain menangkap ikan adalah petambak. Untuk kegiatan off farm masyarakat mengolah ikan (kerupuk ikan, abon ikan, terasi), ikan asin, buruh tambak. Sedangkan untuk kegiatan non farm sebagai pedagang, penyedia jasa penyeberangan, tukang bangunan, tukang bengkel kapal (docking), dan sebagainya. Di Tri Desa Morodemak kegiatan diversifikasi usaha, terutama bagi rumah tangga nelayan miskin belum berjalan dengan baik, disebabkan kendala pemasaran dan modal.
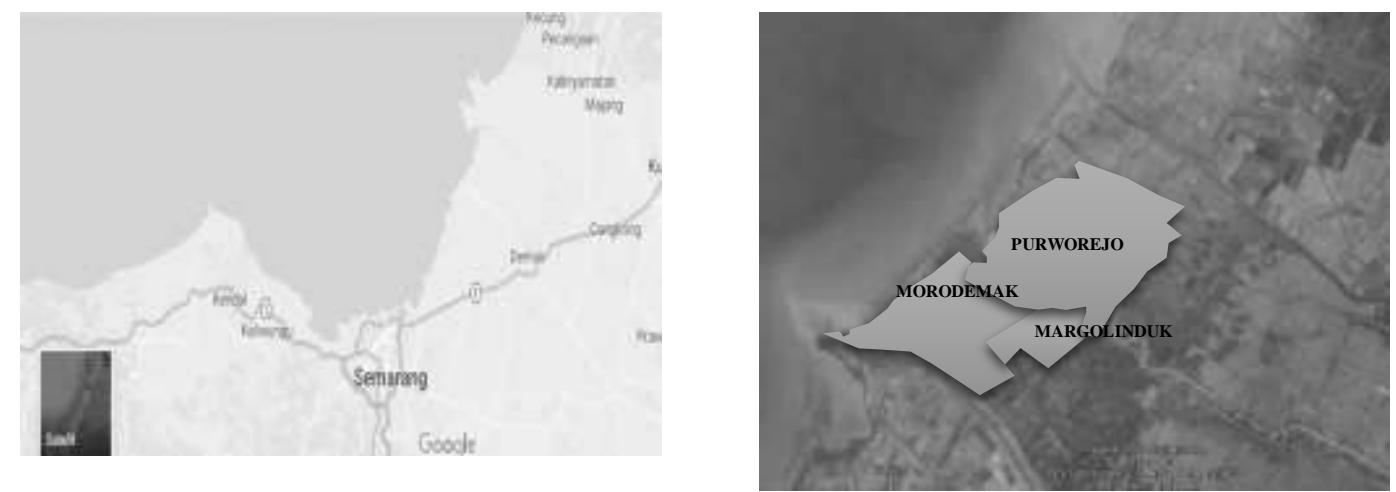

Peta 2. Desa Morodemak 


\section{POLA PENGHIDUPAN BERKELANJUTAN}

\section{Desa Kawa}

Masyarakat Desa Kawa membagi penghasilan mereka ke dalam skema harian dengan mata pencaharian ikan, bulanan dengan kebun coklat dan kopra, serta tanaman tahunan cengkeh. Pekarangan rumah ditanami tumbuhan kebutuhan sehari-hari, seperti rica, jeruk limau, tomat, terung, belimbing wuluh, mangga, singkong racun (untuk bahan baku swami, hanya untuk masyarakat Buton). Masyarakat asli Seram di Kenegerian Kawa ini juga masih memiliki dusun sagu, sekitar $5 \mathrm{~km}$ dari permukiman.

Sebagian masyarakat memiliki ternak sapi, dengan lahan penggembalaan yang sudah mereka bagi di sekitar sempadan sungai, dengan model sewa memakai teknik lelang atau undian (lelang dalam masyarakat Kawa juga berarti undian. Masyarakat yang belum pernah mendapatkan jatah ladang penggembalaan dapat giliran untuk diundi namanya, sementara yang pernah mendapatkan bisa menyewa dari yang memenangkan lelang).

Bahan makanan dari luar desa, antara lain adalah minyak sayur, bawang merah, bawang putih, beras. Pencetakan sawah telah dimulai di dusun Waetoso, yang diusahakan oleh transmigran dari Jawa. Bahan makanan dari dalam desa; aneka sayuran seperti rica, timun, kacang, umbi-umbian. Sedangkan sumber protein utama adalah ikan yang dikelola secara lestari.

\section{Relasi produksi}

Relasi produksi di desa ini khususnya Desa Waeyoho dan Pondok Batu yang warganya keturunan Buton mengenal sistem patron klien dengan jaringan sampai ke kota Ambon dan daerah asal (P. Buton). Dusun Waeyaho penghasilan utama adalah ikan karang (kerapu) dan ikan pelagis (cakalang, tuna). Sedangkan untuk wilayah Pohon Batu, penghasilan utama kepiting, ikan karang.
Relasi produksi di Dusun Kawa, lebih didominasi sistem komunal dengan pembagian dan distribusi kekayaan diatur berdasarkan aturan adat, mulai dari lelang padang penggembalaan di darat, sasi darat untuk kebun pala dan cengkeh, kelapa, sagu. Dan sasi laut untuk perikanan tangkap, seperti; ikan karang, kepiting dan udang.

Perempuan di Dusun Kawa, Waeyoho, dan Pohon Batu juga membuat kopra. Kopra adalah komoditas dominan yang merupakan penghasil utama di desa ini.

\section{Desa Morodemak}

Sistem mata pencarian masyarakat Morodemak pada umumnya adalah nelayan. Nelayan di desa ini terbagi menjadi dua yakni nelayan besar yang memiliki kapal sendiri dan nelayan ikutan atau yang biasa dikenal dengan sebutan ABK (anak buah kapal). Selain nelayan, nelayan tambak juga memiliki proporsi yang cukup besar di desa ini. Mata pencaharian sebagai pedagang dan penyedia jasa lainnya merupakan mata pencarian paling sedikit yang ditemukan di Tri Desa Morodemak.

Nelayan umumnya melaut saat musim angin timur yang ditandai dengan gelombang laut yang relatif tenang. Pada saat musim angin barat dengan gelombang laut yang tinggi masyarakat lebih banyak melakukan kegiatan lain seperti membenarkan perahu atau menjadi nelayan tambak. Pada umumnya nelayan menjalin hubungan dengan pengumpul ikan. Hasil tangkapan kemudian dibeli oleh pengumpul untuk selanjutnya dipasarkan ke tempat lain. Hubungan antara nelayan dan pengumpul sangat baik karena dihubungkan dengan ikatan kepercayaan. Hubungan ABK dengan pemilik kapal dalam hal ini nelayan utama juga demikian.

Penghasilan lain dari para nelayan di Tri Desa Morodemak adalah usaha tambak bandeng dan udang. Seperti yang disebutkan di atas, perubahan ekologi menyebabkan penurunan produksi tambak, sehingga masyarakat, terutama masyarakat miskin yang tidak berlahan tambak kesulitan untuk mendapatkan penghasilan lain, terutama dalam musim paceklik. Sebagian besar 
usaha tambak kepemilikan lahannya mulai beralih dari masyarakat ke pengusaha asal Semarang dan Jakarta.

\section{Relasi produksi}

Relasi produksi di desa ini ada berbagai jenis, yang biasa terjadi adalah hubungan syirkah/kongsi atau dalam bahasa lokal disebut mbageni dengan perbakalan. Perbakalan yang dimaksud adalah perdagangan toko (bekal melaut) dengan pembeli yaitu nelayan. Toko yang dimaksud menyediakan barang yang dibutuhkan.

Penentuan harga perbakalan ini memiliki beberapa skema, yaitu (1) ditentukan oleh pemilik perahu sampan kecil, hal ini disebabkan karena modal untuk sampan kecil sedikit; (2) ditentukan oleh pemilik toko jika pemilik perahu sedang (motik) yang meminta hingga terjadi tawar menawar. Faktor lain dalam penentuan besarnya harga antara lain jumlah utang pemilik perahu kepada pihak toko; (3) ditentukan sepenuhnya oleh pemilik toko jika permintaan bakal dilakukan oleh pemilik perahu besar. Biasanya pemilik toko meminta pelunasan utang lama terlebih dahulu.

Jika dilihat dari pentagon sumber daya, maka kondisi aset-akses-aktivitas produksi dapat dilihat sebagai berikut.

Tabel 3. Kondisi Aktual Aset-Akses dan Aktivitas Produksi

\begin{tabular}{|c|c|c|c|}
\hline \multicolumn{2}{|c|}{ Faktor-faktor PB } & Desa Morodemak & Desa Kawa \\
\hline \multirow[t]{14}{*}{ Kondisi Aset } & Alam & $\begin{array}{l}\text { Laut sebagai mata pencaharian } \\
\text { utama }\end{array}$ & $\begin{array}{l}\text { Laut sebagai mata pencaharian utama } \\
\text { dusun Waeyoho dan Pondok Batu }\end{array}$ \\
\hline & & $\begin{array}{l}\text { Kawasan bakau sebagai budi daya } \\
\text { tambak dan destinasi pariwisata }\end{array}$ & $\begin{array}{l}\text { Kawasan perkebunan dan hutan sebagai } \\
\text { mata pencaharian utama dusun Kawa }\end{array}$ \\
\hline & & Matahari sebagai alat pengering & $\begin{array}{l}\text { Kayu bakar untuk membakar dan } \\
\text { mengasap ikan }\end{array}$ \\
\hline & & $\begin{array}{l}\text { Kawasan tak terbangun (hutan } \\
\text { bakau, empang, badan air) } \\
\text { mencakup sekitar } 90 \% \text { wilayah } \\
\text { desa. }\end{array}$ & $\begin{array}{l}\text { Kawasan tak terbangun (kebun, hutan } \\
\text { adat, hutan Mangrove) mencakup sekitan } \\
\text { 95\% wilayah desa }\end{array}$ \\
\hline & Fisik & $\begin{array}{l}\text { Alat tangkap modern, pukat, kursin, } \\
\text { arat }\end{array}$ & $\begin{array}{l}\text { Alat tangkap tradisonal untuk sebagian } \\
\text { besar nelayan }\end{array}$ \\
\hline & & $\begin{array}{l}\text { Alat tangkap tradisional, pancing, } \\
\text { bubu untuk nelayan miskin }\end{array}$ & Alat tangkap tradisional, pancing, bubu \\
\hline & & $\begin{array}{l}\text { Aktivitas pusat pelelangan ikan } \\
\text { buatan pemerintah berfungsi }\end{array}$ & $\begin{array}{l}\text { Aktivitas tempat pelelangan ikan buatan } \\
\text { pemerintah tidak berfungsi }\end{array}$ \\
\hline & & Kondisi permukiman padat & $\begin{array}{l}\text { Kondisi permukiman nyaman, dengan } \\
\text { pekarangan luas }\end{array}$ \\
\hline & & $\begin{array}{l}\text { Kepemilikan kendaraan terutama } \\
\text { motor dan mobil serta perahu }\end{array}$ & $\begin{array}{l}\text { Kepemilikan kendaraan terutama motor } \\
\text { dan perahu }\end{array}$ \\
\hline & & $\begin{array}{l}\text { Kepemilikan barang } \\
\text { seperti perlengkapan } \\
\text { rumah) hampir rata }\end{array}$ & $\begin{array}{l}\text { Kepemilikan barang konsumsi seerti } \\
\text { perabotan rumah tidak merata }\end{array}$ \\
\hline & $\begin{array}{l}\text { Manu } \\
\text { sia }\end{array}$ & $\begin{array}{l}\text { Tingkat pendidikan tinggi SMA } \\
\text { dan PT di kalangan generasi muda } \\
\text { kelahiran 1990-an }\end{array}$ & $\begin{array}{l}\text { Tingkat pendidikan SMA di kalangan } \\
\text { generasi muda kelahiran 1990-an }\end{array}$ \\
\hline & & $\begin{array}{l}\text { Terdapat berbagai pelatihan } \\
\text { keterampilan rumah tangga nelayan }\end{array}$ & $\begin{array}{l}\text { Jarang terdapat peningkatan kapasitas } \\
\text { rumah tangga nelayan }\end{array}$ \\
\hline & Sosial & $\begin{array}{l}\text { Sistem kekerabatan (perkawinan) } \\
\text { dan kebertetetanggaan, status } \\
\text { ekonomi menentukan status sosial, } \\
\text { kapasitas intelektual memengaruhi } \\
\text { status sosial }\end{array}$ & $\begin{array}{l}\text { Sistem kesukuan berdasarkan marga, } \\
\text { status keturunan (raja) menentukan status } \\
\text { eknomi }\end{array}$ \\
\hline & & $\begin{array}{l}\text { Gotong royong dalam kampung } \\
\text { untuk kerja bakti di wilayah } \\
\text { permukiman }\end{array}$ & $\begin{array}{l}\text { Komunalisme dan sumber daya milik } \\
\text { bersama (sasi darat dan sasi laut) }\end{array}$ \\
\hline
\end{tabular}


Tabel 4. Lanjutan

\begin{tabular}{|c|c|c|}
\hline Faktor-faktor PB & Desa Morodemak & Desa Kawa \\
\hline \multirow[t]{4}{*}{$\begin{array}{r}\text { Finansial } \\
\end{array}$} & $\begin{array}{l}\text { Modal diambil tabungan individu, } \\
\text { sebagian besar nelayan miskin dan } \\
\text { nelayan tambak } \\
\text { Modal dari juragan kapal, dari } \\
\text { Semarang dan Jakarta }\end{array}$ & $\begin{array}{l}\text { Modal sendiri untuk sebagian besar } \\
\text { nelayan } \\
\text { Juragan kapal, biasanya dilakukan oleh } \\
\text { masyarakat Buton }\end{array}$ \\
\hline & Perbakalan (qiraadh) & Pembeli ikan \\
\hline & $\begin{array}{l}\text { Modal pinjaman Bank untuk } \\
\text { pengusaha tambak }\end{array}$ & $\begin{array}{l}\text { Perbankan, dimulai ketika komoditas } \\
\text { coklat mulai tren }\end{array}$ \\
\hline & $\begin{array}{l}\text { Modal simpan pinjam perempuan } \\
\text { untuk usaha industri rumah tangga }\end{array}$ & \\
\hline \multirow[t]{7}{*}{$\begin{array}{l}\text { Kondisi } \\
\text { Akses }\end{array}$} & Pemasaran tangkapan ke TPI & $\begin{array}{l}\text { Pemasaran hasil ikan laut, kepiting, ke } \\
\text { Ambon }\end{array}$ \\
\hline & $\begin{array}{l}\text { Pemasaran ikan tambak (udang dan } \\
\text { bandeng) ke Semarang }\end{array}$ & Pemasaran ke Piru (kota kecamatan) \\
\hline & $\begin{array}{l}\text { Kondisi sarana dan prasarana } \\
\text { perikanan mendukung }\end{array}$ & $\begin{array}{l}\text { Akses jalan ke ibukota kecamatan dan } \\
\text { kabupaten baik }\end{array}$ \\
\hline & $\begin{array}{l}\text { Akses jalan ke kota kecamatan dan } \\
\text { Kabupaten baik }\end{array}$ & $\begin{array}{l}\text { Transportasi umum terbatas waktu dan } \\
\text { jarang }\end{array}$ \\
\hline & Transportasi umum banyak & $\begin{array}{l}\text { Akses terhadap sumber daya alam besar, } \\
\text { diatur oleh desa }\end{array}$ \\
\hline & $\begin{array}{l}\text { Sebagian besar masyarakat } \\
\text { bergantung pada laut, akases } \\
\text { terhadap sumber daya alam, } \\
\text { terutama tambak terbatas karena } \\
\text { lebih banyak kepemilikan privat }\end{array}$ & $\begin{array}{l}\text { Aktivitas melaut dan ladang bagi orang } \\
\text { asli hampir sama }\end{array}$ \\
\hline & $\begin{array}{l}\text { Akses terhadap pengambilan } \\
\text { keputusan hampir setara di semua } \\
\text { kalangan masyarakat, musyawarah } \\
\text { dilakukan secara rutin }\end{array}$ & $\begin{array}{l}\text { Akses pengambilan keputusan bersifat } \\
\text { elitis, dengan sistem perwakilan marga } \\
\text { dan perangkat desa }\end{array}$ \\
\hline \multirow[t]{4}{*}{ Aktivitas } & $\begin{array}{l}\text { Ada pembagian kerja } \text { antara } \\
\text { perempuan dan laki-laki } \\
\text { aktivitas nelayan }\end{array}$ & $\begin{array}{l}\text { Ada pembagian kerja antara perempuan } \\
\text { dan laki-laki dalam aktivitas nelayan dan } \\
\text { perkebunan }\end{array}$ \\
\hline & Untuk keluarga $\mathrm{ABK}$ ada yang & Aktivitas domestik lebih banyak di Dusun \\
\hline & $\begin{array}{l}\text { menjadi pekerja harian lepas pada } \\
\text { tambak. }\end{array}$ & $\begin{array}{l}\text { Kawa dan Waeyaho untuk perempuan, } \\
\text { sementara di Dusun Pondok Batu, } \\
\text { perempuan menentukan harga lelang ikan }\end{array}$ \\
\hline & $\begin{array}{l}\text { Perempuan membuat ikan asin dan } \\
\text { kerupuk ikan }\end{array}$ & $\begin{array}{l}\text { Perempuan lebih dominan dalam } \\
\text { pekerjaan kebun (membersihkan lahan), } \\
\text { dan membuat kopra. }\end{array}$ \\
\hline
\end{tabular}

\section{Desa Kawa}

Desa Kawa memiliki pentagon aset produksi sebagai berikut, aset alam merupakan aset utama dari pentagon aset yang pengaturannya diatur secara komunal sebagai aset sosial. Kedua aset ini, terutama aset sosial telah menempatkan kelompok miskin dalam jaring pengaman sosial yang menyebabkan mereka berada dalam skema penghidupan berkelanjutan yang lestari dan sejahtera.

Dari sisi aset sumber daya keuangan, untuk Desa Kawa tidak memiliki struktur akses finansial yang timpang, kepemilikan lahan rata- rata di desa adalah 2 hektar, yang ditanami kebun campur. Orang yang terkaya biasanya sekarang menanam coklat, baik pendatang maupun orang adat. Adanya dusun sagu dan kebun campur komunal menjadikan ketimpangan sosial kecil, karena masing-masing keluarga sesuai dengan marganya telah mendapatkan jatah dari adat.

Bagi penghuni adat (pendatang) kesulitan yang dialami sekarang adalah penambahan lahan, baik untuk permukiman maupun untuk perkebunan. Hal ini dialami terutama oleh dusun Pohon Batu, yang sebagian wilayahnya adalah wilayah lindung bakau dan pasang surut. Sedangkan daerah lahan kering subur yang 
masih tersisa dari luas desa, seluas 350 hektar telah diberikan kepada Kepolisian Republik Indonesia ${ }^{2}$.

Bagi orang adat Kenegerian Kawa yang tergabung dalam Aliansi Masyarakat Adat Nusantara ini permasalahan aset dan akses lahan menjadi isu utama, mengingat permasalahan ini pun yang sering menjadi pemicu konflik dan dianggap menjadi penyebab kemunduran ekonomi orang adat. Perlindungan orang adat terhadap aset sumber daya alam ini menyebabkan ketimpangan antar masyarakat tidak besar di kalangan orang adat.

Permasalahan lahan yang dialami dusun lain seperti dusun Waeyoho adalah ekstensifikasi lahan perkebunan coklat. Sedangkan untuk Dusun Pohon Batu adalah luasan untuk wilayah permukiman.

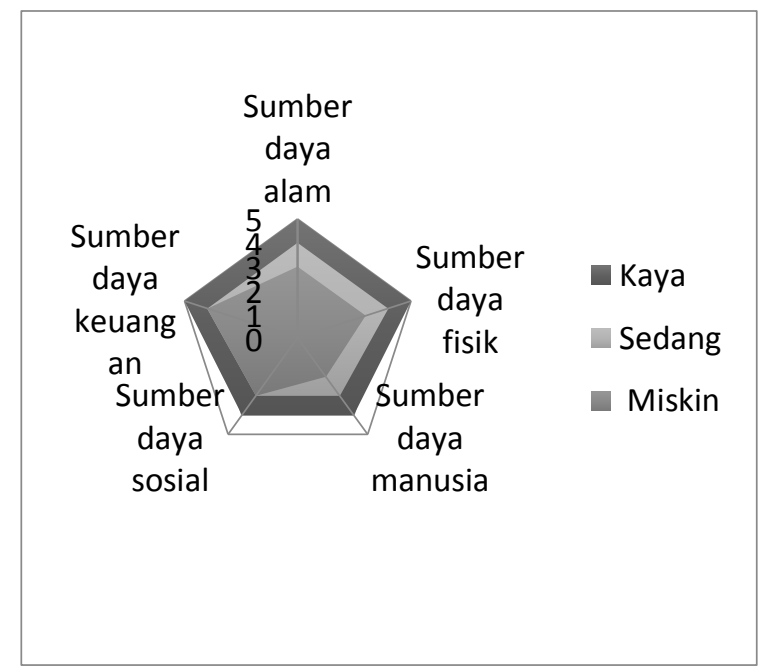

Grafik 1. Kepemilikan Aset Penghidupan Berkelanjutan Desa Kawa

\section{Desa Morodemak}

Desa Morodemak memiliki kepemilikan aset produksi sebagai berikut; sebanyak $60 \%$ responden memiliki lahan tambak. Selain sebagai petani tambak, mereka bekerja sebagai anak buah kapal. Dari sisi kepemilikan sumber daya lahan kelompok kaya sekurangnya memiliki lebih dari 2 ha tambak dan perahu yang

2 Menurut La Hadia kepala dusun Pohon Batu, sekitar tahun 1985 terjadi proses penyerahan tanah kepada Kepolisan Republik Indonesia, dan setiap tahun masyarakat dijanjikan bisa mendaftar menjadi anggota Polri (saat itu bisa disewakan. Sistem sewa tambak tergantung dari lokasi tambak, ada tambak yang dianggap sebagai lokasi yang tepat dilihat dari (1) ketersediaan saluran air untuk sirkulasi air tambak; (2) asal-usul lahan tambak, ada sebagian lahan yang muncul karena sedimentasi; (3) pengaruh hutan bakau dalam sebagai penghasil unsur hara dalam tambak. Harga lahan di lokasi terbaik dalam kisaran 30 juta per tahun, biasanya lahan tambak disewakan paling kurang 3 tahun.

Sedangkan kepemilikan aset produksi untuk golongan sedang, adalah kepemilikan perahu kecil atau sedang. Dengan kepemilikan tambak di bawah 2 hektar. Bagian terbesar masyarakat adalah nelayan tanpa aset produksi, baik tambak maupun perahu.

Dari sisi sumber daya manusia, kaum kaya berhasil menetaskan anaknya terutama generasi 1990-an untuk bersekolah sampai ke Perguruan Tinggi, sedangkan kaum paling miskin bersekolah sampai tingkat SMA. Sebagian besar masyarakat yang berstatus sedang, menyekolahkan anak mereka setelah lulus SMA di sekitar kota Demak untuk memenuhi kualifikasi pekerjaan di luar sektor perikanan tangkap dan tambak.

Dari sisi sosial, kaum kaya bisa mendapatkan akses melalui pengaruh kekayaan, namun sebagai desa yang masih memerhatikan nilai-nilai agama, status kaum terdidik, baik dalam hal agama, maupun pengetahuan umum bisa memengaruhi pilihan masyarakat dalam hal kepemimpinan. Akses terhadap pengambilan keputusan hampir sama pada setiap status kekayaan, musyawarah berjalan rutin, namun untuk kesempatan berorganisasi kebanyakan perempuan kaum miskin tidak sempat melakukan peningkatan kapasitas karena menjadi buruh lepas di tambak atau mencari penghasilan lain.

Secara ringkas gambaran hubungan pentagon aset Desa Morodemak digambarkan dalam Grafik 2 di bawah ini.

masih tergabung dengan TNI). Sejak proses penyerahan lahan tersebut menjadi lahan tidur, pasca konflik Ambon baru pihak Kepolisian memasang plang tanda petak tanah tersebut dikuasai oleh Kepolisian. 


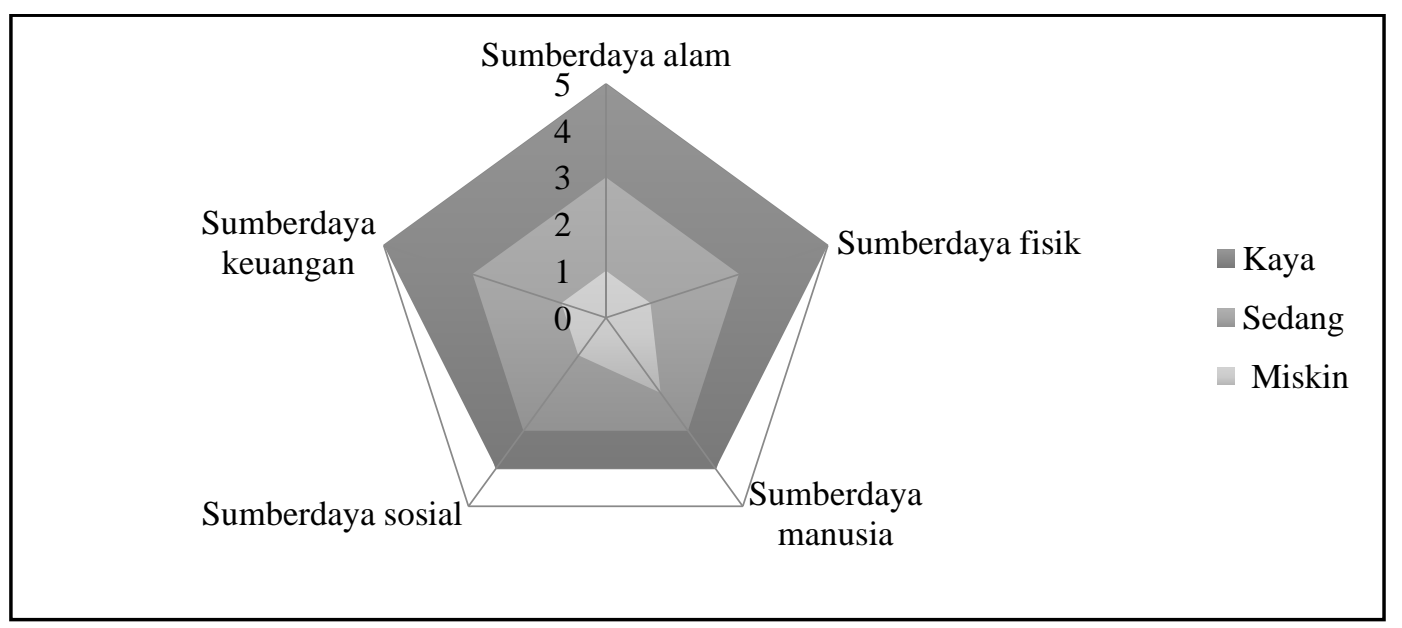

Grafik 2. Kepemilikan aset penghidupan berkelanjutan Desa Morodemak pendahulu mereka yang bisa membuat mereka

\section{POLA MIGRASI}

\section{Desa Kawa}

Desa Kawa (Kenegerian Kawa) adalah desa adat yang memiliki sejarah panjang migrasi dan telah berhubungan lama dengan Kenegerian lain sejak sebelum jaman penjajahan. Negeri Kawa atau Hena merupakan kumpulan dari marga-marga yang kemudian berkumpul menjadi marga, (1) Soa Ely; terdiri dari marga Ely, Kiwe, Rotasouw dan (2) Soa Nurue; terdiri dari marga Rotasouw, Nurue, Lessy ${ }^{3}$. Orang Buton mulai masuk Desa Kawa diperkirakan sejak tahun 1600-an.

Masyarakat Desa Kawa, baik orang adat dan penghuni adat memiliki karakter menetap. Asal mula dusun Kawa pun jika dilihat dari sejarahnya berasal dari masyarakat dataran tinggi, peramu dan pekebun ladang, yang kemudian datang ke pantai disebabkan oleh gangguan roh, yang menurut tetua mereka mengharuskan penduduk untuk turun ke arah pantai.

Dari sejarah yang tidak boleh dituliskan itu (menurut Hamzah, jika sejarah dituliskan akan hilang tuahnya dan berhenti menjadi sejarah yang diikuti oleh masyarakat) masyarakat percaya bahwa tanah Desa Kawa yang ada sekarang adalah tanah pilihan

3 Wawancara langsung dengan Hamzah, mantan Raja Kawa, sebutan raja dalam wilayah kenegerian sama selamat dari gangguan roh dan penyakit.

Jika dilihat dari sisi pekerjaan yang sebagian besar nelayan dan pekebun dari karakteristik lokasi hunian, maka dapat dilihat perwujudan desa dan dusun-dusun sejak awal hunian memiliki orientasi hunian permanen dan dekat dengan tempat kerja. Dalam perencanaan tata guna lahan pun masyarakat telah menetapkan lokasi-lokasi yang berhubungan dengan orientasi lokasi hunian, terutama dalam menetapkan fasilitas publik seperti pasar, sekolah, lapangan olah raga.

Fasilitas publik dan ruang publik sebagai tempat interaksi antar individu atau kelompok dalam Setiawan dan Barret (2016) dapat menjadi jembatan dalam pemulihan pasca konflik. Dalam konteks Desa Kawa apa yang disebut sebagai 'heritage economy' seperti panen cengkeh bersama dapat kembali dijadikan.

Sedangkan dari sisi aktivitas masyarakat kegiatan tahunan yang membuat masyarakat untuk melakukan migrasi keluar adalah panen cengkeh di Piru, yang berjarak sekitar $30 \mathrm{~km}$ dari Desa Kawa. Panen cengkeh ini terutama ramai dikunjungi oleh orang Buton, yang menjadi pemilik kebun cengkeh di daerah Seram Barat, termasuk kecamatan Piru. Namun ikatan kultural pela yang biasanya bisa menjembatani antar kerabat yang berbeda marga, identitas agama, sejak terjadinya konflik Ambon membuat

dengan kepala desa dalam administrasi wilayah NKRI, 20 Oktober 2015. 
masyarakat tersegregasi atas identitas agama. Konflik agama ini juga yang membuat budaya gotong royong dalam panen cengkeh menjadi berkurang.

Akibat konflik lainnya adalah lahan-lahan yang dipersiapkan untuk pengungsi, untuk menerima kerabat korban konflik berdasarkan pela (ikatan kekerabatan berdasarkan perkawinan saudara laki-laki) gandong (ikatan kekerabatan berdasarkan geneologis desa/hena), dan famili (hubungan kekerabatan berdasarkan kesamaan marga/fam) ${ }^{4}$. Persiapan lahan ini diakui oleh Hamzah sebagai salah satu cara untuk membantu saudara mereka sesuai dengan ikatan adat di atas. Migrasi ke dalam muncul dalam periode 1999 hingga 2007 untuk menampung para pengungsi ini, namun bersifat sementara, sampai rekonsiliasi terjadi. Rekonsiliasi pertama terjadi di tahun $2007^{5}$ dilakukan di hutan adat, yang pengelolaannya milik marga-marga yang saling berhubungan antar hena/desa dan menjadi sumber daya milik bersama.

Dampak lanjutan dari konflik ini adalah terbatasnya ekspansi lahan bagi perkebunan cengkeh dan coklat bagi petani Buton dari Buton dan daerah kepulauan Maluku dan sekitarnya.

Tabel 5. Karakteristik pilihan lokasi hunian Desa Kawa

\begin{tabular}{|c|c|c|c|}
\hline & \multicolumn{3}{|l|}{ Karakteristik pilihan lokasi hunian } \\
\hline \multirow[t]{7}{*}{1.} & \multicolumn{3}{|l|}{ Pilihan orientasi arah rumah } \\
\hline & Cahaya matahari & : & $\begin{array}{l}\text { Cukup, rumah yang ada menghadap ke arah } \\
\text { jalan-jalan, yang membentuk grid dan blok- } \\
\text { blok permukiman }\end{array}$ \\
\hline & \multirow[t]{2}{*}{ Kemudahan sirkulasi menuju tempat kerja } & : & $\begin{array}{l}\text { Iya, dengan mayoritas masyarakat Buton } \\
\text { yang masih memiliki rumah panggung, dan } \\
\text { berdekatan dengan pantai/dermaga tambat } \\
\text { perahu. }\end{array}$ \\
\hline & & & $\begin{array}{l}\text { Masyarakat pekebun Desa Kawa memiliki } \\
\text { lokasi usaha yang jauh dari permukiman. } \\
\text { Rata-rata dusun sagu dan kebun campur } \\
\text { berjarak lebih dari dua kilometer dari } \\
\text { permukiman. }\end{array}$ \\
\hline & Kemudahan menambat perahu & & $\begin{array}{l}\text { Ya, jarak rata-rata permukiman dengan } \\
\text { tambatan perahu terjauh } 700 \text { meter }\end{array}$ \\
\hline & Kemudahan menghadapi bencana & & $\begin{array}{l}\text { Ya, pohon kelapa dan ketapang yang } \\
\text { menjadi sekat antara ruang terbuka pantai } \\
\text { dan permukiman, sekaligus menahan badai } \\
\text { tahunan }\end{array}$ \\
\hline & Adat & & $\begin{array}{l}\text { Ya, dari sisi tata letak rumah dan pembagian } \\
\text { ruang, baik di luar dengan adanya walang } \\
\text { (bale-bale) di setiap rumah dan dua ruang } \\
\text { penerima tamu, memperlihatkan kualitas } \\
\text { komunikasi antara tamu dengan penghuni } \\
\text { rumah. }\end{array}$ \\
\hline
\end{tabular}

${ }^{4}$ Untuk penjelasan lebih jauh tentang konflik dan rekonsiliasi berdasarkan kearifan lokal ini bisa melihat Wakano, Abidin. 2009. Dampak Konflik Maluku: Studi Konflik dan Kekisruhan pada Pengungsi Iha, Kayu Tiga dan, Seriholo dalam Agama Dan Pergeseran Representasi: Konflik Dan Rekonsiliasi Di Indonesia, Penerbit Wahid Institute

\footnotetext{
${ }^{5}$ Menurut Hamzah, rekonsiliasi yang diinisiasi pemerintah tidak pernah berhasil mendamaikan pihak yang bertikai, rekonsiliasi baru tercapai setelah semua pihak merasakan kebutuhan perdamaian, terutama ketika sumber penghidupan mereka, hutan dan kebun campur tidak bisa diolah karena perang, 20 Oktober 2015.
} 
Tabel 6. Lanjutan

\begin{tabular}{|c|c|c|c|}
\hline & \multicolumn{3}{|l|}{ Karakteristik pilihan lokasi hunian } \\
\hline \multirow[t]{4}{*}{2.} & $\begin{array}{l}\text { Pilihan bahan bangunan yang } \\
\text { digunakan }\end{array}$ & & \\
\hline & Awet & : & $\begin{array}{l}\text { Ya, khusus untuk dusun Pohon Batu, } \\
\text { pemilihan material rumah tergantung } \\
\text { dari status ekonomi. }\end{array}$ \\
\hline & Mudah dicari & : & $\begin{array}{l}\text { Ya, sebagian besar balok rumah } \\
\text { menggunakan kayu kelapa. }\end{array}$ \\
\hline & Mudah dipelihara & $:$ & $\mathrm{Ya}$ \\
\hline \multirow[t]{5}{*}{3.} & Arsitektur & & \\
\hline & Tradisi & $:$ & $\begin{array}{l}\text { Tidak, kecuali di dusun Pohon Batu. } \\
\text { Dalam hal pembagian ruang, dapur } \\
\text { terpisah dengan rumah inti di dusun } \\
\text { Waeyaho. }\end{array}$ \\
\hline & Tren & : & $\mathrm{Ya}$ \\
\hline & Kebutuhan ruang & : & $\mathrm{Ya}$ \\
\hline & Kebutuhan privasi & $:$ & $\mathrm{Ya}$ \\
\hline \multirow[t]{7}{*}{4.} & Konstruksi yang digunakan & & \\
\hline & $\begin{array}{l}\text { Tahan terhadap perubahan cuaca yang } \\
\text { ekstrim }\end{array}$ & : & $\mathrm{Ya}$ \\
\hline & $\begin{array}{l}\text { Tahan akan gangguan luar/binatang } \\
\text { buas }\end{array}$ & : & $\begin{array}{l}\text { Ya, pola permukiman yang berbentuk } \\
\text { grid di dalam permukiman dikelilingi } \\
\text { oleh kebun-kebun pekarangan di } \\
\text { halaman belakang yang cukup luas, } \\
\text { dengan gerbang desa yang cukup jauh } \\
\text { dari pusat permukiman, sekitar } 1 \mathrm{~km} \text {. }\end{array}$ \\
\hline & & & $\begin{array}{l}\text { Lokasi pertama dari gerbang desa } \\
\text { adalah fasilitas sekolah dan pasar } \\
\text { sementara. Baru terdapat rumah-rumah } \\
\text { dengan pekarangan depan dan belakang } \\
\text { yang cukup luas. }\end{array}$ \\
\hline & Tahan untuk generasi mendatang & $:$ & $\begin{array}{l}\text { Ya, pembangunan rumah sekarang } \\
\text { menggunakan bahan campuran antara } \\
\text { bata dan semen, serta kayu. pilihan ini } \\
\text { tergantung tingkat ekonomi rumah } \\
\text { tangga bersangkutan. }\end{array}$ \\
\hline & Dapat diubah per bagian & : & $\begin{array}{l}\text { Ragu, kemungkinan perubahan adalah } \\
\text { perluasan horizontal untuk rumah } \\
\text { tumbuh. }\end{array}$ \\
\hline & Kebutuhan tinggal sementara & $:$ & $\begin{array}{l}\text { Tidak, semua rumah dibangun secara } \\
\text { permanen dengan material yang } \\
\text { tersedia. }\end{array}$ \\
\hline
\end{tabular}

\section{Desa Morodemak}

Migrasi sementara yang terjadi di Morodemak terutama disebabkan kehadiran para anak buah kapal (ABK) dari daerah sekitarnya, seperti Tegal, Kudus dan Rembang. Kehadiran pendatang ini bersifat sementara, namun dalam intensitas yang sering. Akibat penyempitan lahan untuk kawasan permukiman, generasi kemudian di desa ini memilih tinggal di luar desa, walaupun masih dalam satu kecamatan Bonang. 
Tabel 7. Karakteristik pilihan lokasi hunian Desa Morodemak

\begin{tabular}{ll}
\hline \multicolumn{3}{l}{ Karakteristik pilihan lokasi hunian } \\
\hline Orientasi arah rumah \\
Cahaya matahari
\end{tabular}

Kemudahan sirkulasi menuju tempat kerja

Kemudahan menambat perahu

Kemudahan menghadapi bencana

Adat

2. Bahan bangunan yang digunakan Awet

Mudah dicari

Mudah dipelihara

3. Arsitektur

Tradisi

Tren

Kebutuhan ruang

Kebutuhan privasi

4. Konstruksi yang digunakan

Tahan terhadap perubahan cuaca yang : Ya

ekstrim

Tahan akan gangguan luar/binatang buas

Tahan untuk generasi mendatang Dapat diubah per bagian

Kebutuhan tinggal sementara
: Tidak, rumah lebih mementingkan sirkulasi udara dan kebutuhan untuk menampung air, sehingga walaupun padat namun jarak antar rumah tetap dijaga (sekitar $50 \mathrm{~cm}$ ). Hal ini menurut warga untuk menjaga sirkulasi udara, di samping adanya talang air untuk menampung curahan air hujan ke bak penampungan di dalam dan luar rumah.

: Ragu, kecuali untuk yang berpenghasilan nelayan, desa ini cukup jauh untuk orang yang memiliki pekerjaan di luar profesi nelayan. Dari ibukota kabupaten desa ini berjarak sekitar $12 \mathrm{~km}$.

: Ya, terdapat dermaga di sepanjang sungai utama

: Tidak, masyarakat desa terbiasa dengan rob setiap bulan yang biasa merendam $50 \mathrm{~cm}$ permukiman. Penataan permukiman dan ruang terbuka hijau tidak dilakukan oleh masyarakat, hampir seluruh ruang terbuka ditutup semen dengan saluran yang sempit.

: Tidak, semua rumah yang dibangun mengikuti tren masa kini, kecuali beberapa bangunan tua yang belum direnovasi (karena keterbatasan dana).

: Ya, bahan bangunan yang digunakan seluruhnya dari bata dan semen.

: Ya, jumlah penjual toko bahan bangunan banyak

: Ya, dengan adanya banjir rob, beberapa bangunan baru terlihat menggunakan finishing keramik untuk dinding, guna memudahkan pembersihan.

: Tidak, bangunan baru mengikuti tren dan pemanfaatan keterbatasan lahan.

: Ya

: Ya

: Tidak, ruang rumah yang sempit menyebabkan masyarakat cuma memiliki satu ruang serbaguna untuk menerima tamu, makan, dan tidur dengan kasur lipat.

: Tidak, karena jauh dari lokasi tambak. Kemungkinan binatang buas yang menyasar ke permukiman adalah ular sanca.

: Ya

: Ragu, kemungkinan rumah diperluas hanya dengan pembangunan vertikal

: Ya, untuk sebagian rumah sewa, dibangun dengan material dan konstruksi seadanya. 
Jika dilihat dari sejarah pembentukan desa, yaitu komunitas nelayan yang bertempat tinggal bersama-sama (moro) dekat dengan tempat mereka melaut, maka pola migrasi yang berlangsung masih sama, yaitu adanya penduduk musiman yang datang secara intens dan berkala. Perubahan yang terjadi justru karena penyempitan lahan wilayah permukiman, hal ini mendorong terjadinya migrasi ke luar desa untuk mencari permukiman yang lebih layak.

Walaupun Desa Morodemak 90\% memiliki lahan terbuka yang terdiri dari tambak dan hutan Mangrove, namun masyarakat memilih untuk pindah ke luar desa disebabkan mata pencaharian generasi yang lahir kemudian (lahir tahun 1990-an) bukan nelayan atau petambak. Di samping itu, lahan-lahan yang ada tidak lagi dimiliki sebagian besar masyarakat, namun investor dari luar desa. Bagi sebagian warga desa tanpa lahan ini, mempertahankan tambak merupakan salah satu cara untuk mempertahankan kehidupan mereka dengan bekerja di tambak-tambak orang lain.

\section{Strategi Adaptasi}

Konversi dan diversifikasi penggunaan lahan, perubahan komoditas di Desa Kawa dan Morodemak memiliki skenario yang berbeda. Perubahan ini dapat dilihat dengan melihat cara masyarakat mempertahankan kehidupannya. Di Desa Kawa strategi adaptasi dilakukan oleh pendatang dari Buton dengan mengubah komoditas kelapa dan cengkeh, menjadi coklat karena dianggap lebih menguntungkan. Sedangkan secara geografis orang adat semakin meneguhkan posisi teritorial mereka dengan penetapan sasi darat dan laut.

Penetapan sasi darat yaitu larangan memanen tumbuhan atau membuka lahan jika tidak sesuai musim untuk menjaga kebersamaan. Sedangkan sasi laut yang berlangsung selama 2 tahun dan dibuka selama satu bulan, untuk wilayah tangkap 300 meter dari bibir pantai adalah cara orang adat untuk mempertahankan kualitas stok ikan dari penangkapan yang berlebihan dan menjaga suksesinya.

Sedangkan masyarakat Desa Morodemak lebih banyak memanfaatkan keunggulan sumber daya alam mereka untuk mempertahankan mata pencaharian mereka sebagai petambak, sehingga luasan tambak dipertahankan, sedangkan kebutuhan untuk memperbaiki kualitas hunian menjadi prioritas kesekian. Peningkatan aksesibilitas komunikasi dan transportasi publik di kawasan perdesaan menjadi faktor penarik bagi masyarakat untuk melakukan migrasi keluar desa.

Tabel 8. Pilihan strategi adaptasi

\begin{tabular}{|c|c|}
\hline \multicolumn{2}{|r|}{ Strategi Adaptasi Desa Kawa } \\
\hline $\begin{array}{l}\text { Aspek Penghidupan } \\
\text { Berkelanjutan }\end{array}$ & $\begin{array}{l}\text { Aspek sosial dan sumber daya alam merupakan aspek tepenting yang } \\
\text { dipertahankan masyarakat adat Desa Kawa untuk menghadapi perubahan } \\
\text { lingkungan dan perubahan sosial. }\end{array}$ \\
\hline $\begin{array}{l}\text { Aspek Pertambahan } \\
\text { Populasi }\end{array}$ & $\begin{array}{l}\text { Perubahan populasi karena migrasi dibatasi sejak konflik Ambon tahun } \\
1999 .\end{array}$ \\
\hline & $\begin{array}{l}\text { Perubahan dalam migrasi musiman, dari panen cengkeh bersama, menjadi } \\
\text { tidak ada. }\end{array}$ \\
\hline Aspek Geografis & $\begin{array}{l}\text { Rencana tata guna lahan (land use planning) dilakukan dengan } \\
\text { mencadangkan kawasan permukiman untuk generasi mendatang. }\end{array}$ \\
\hline & $\begin{array}{l}\text { Pemberian lahan (hak milik dan hak pakai) kepada pendatang sejak konflik } \\
\text { Ambon mulai berkurang. }\end{array}$ \\
\hline Aspek Sosial-Kultur & $\begin{array}{l}\text { Secara sosial masyarakat terikat oleh aturan pela, gandong, dan famili. Hal } \\
\text { ini juga yang menyebabkan adanya penerimaan atau penolakan pengungsi. }\end{array}$ \\
\hline & $\begin{array}{l}\text { Secara budaya, masyarakat Desa Kawa adalah masyarakat terbuka, ini bisa } \\
\text { dilihat dari harmoninya masyarakat adat dengan pendatang dari Buton sejak } \\
\text { jaman tahun } 1600 \text { dan transmigran Jawa sejak Orde Baru. }\end{array}$ \\
\hline
\end{tabular}


Tabel 9. Lanjutan

\begin{tabular}{|c|c|}
\hline \multicolumn{2}{|r|}{ Strategi Adaptasi Desa Morodemak } \\
\hline $\begin{array}{l}\text { Aspek Penghidupan } \\
\text { Berkelanjutan }\end{array}$ & $\begin{array}{l}\text { Aspek sumber daya alam, terutama lahan tambak adalah aspek terpenting yang } \\
\text { dipertahankan masyarakat. }\end{array}$ \\
\hline & $\begin{array}{l}\text { Aspek penghidupan berkelanjutan yang lain rentan terhadap perubahan, } \\
\text { terutama bagi nelayan miskin yang tidak memiliki perahu atau lahan tambak, } \\
\text { hal ini disebabkan mereka tidak memiliki aset yang sama dengan aktor lain } \\
\text { untuk melakukan mobilisasi sumber daya bagi perbaikan kehidupan }\end{array}$ \\
\hline & $\begin{array}{l}\text { Membentuk kembali sumber daya bersama, yaitu sempadan sungai sebagai } \\
\text { mixed used, dan sungai dan kawasan tambak sebagai daerah penyangga, habitat } \\
\text { satwa, dan destinasi wisata. }\end{array}$ \\
\hline $\begin{array}{l}\text { Aspek Pertambahan } \\
\text { Populasi }\end{array}$ & $\begin{array}{l}\text { Perubahan populasi terjadi karena masyarakat yang tidak lagi bermata } \\
\text { pencaharian nelayan dan memilih pindah karena memiliki kemampuan untuk } \\
\text { mendapatkan hunian lain di luar desa yang lebih sehat. }\end{array}$ \\
\hline Aspek Geografis & $\begin{array}{l}\text { Rencana tata guna lahan (land use planning) tidak memerhatikan kondisi } \\
\text { permukiman yang lebih baik dan adaptif terhadap bencana rob, masyarakat } \\
\text { malah menggusur sempadan sungai untuk perluasan rumah, yang } \\
\text { menyebabkan genangan rob yang terjadi berlangsung lebih lama, dari tahun ke } \\
\text { tahun. }\end{array}$ \\
\hline Aspek Sosial-Kultur & $\begin{array}{l}\text { Secara kultural masyarakat memiliki sikap terbuka dan menerima pendatang, } \\
\text { baik musiman maupun yang ingin menetap atau memiliki lahan tambak sebagai } \\
\text { investor. }\end{array}$ \\
\hline
\end{tabular}

Jika melihat model Ostrom (2006) mengenai sumber daya bersama, maka terlihat bahwa pengaturan sumber daya bersama masih bisa menciptakan tertib sosial, memiliki dampak positif pada penghidupan berkelanjutan, seperti yang terjadi di Desa Kawa. Di desa ini walaupun terdapat kesenjangan antar masyarakat, namun secara sosial mereka mampu menciptakan jaring pengaman sosial lewat aturan adat, sehingga kebutuhan mendasar seperti pangan, papan, dan sandang bisa dicukupi dan diusahakan secara sosial.

Masalah apropriator seperti eksternalitas teknologi terjadi di Desa Morodemak, yaitu konflik alat tangkap. Masalah ini dalam konteks mitigasi, tidak terjadi di Desa Kawa yang menyiapkan aturan main sasi yang bisa dibaca sebagai strategi ekonomi-politik bagi orang adat yang masih menggunakan teknologi alat tangkap tradisional jika dibandingkan pendatang dari Buton yang menggunakan alat tangkap modern dan armada yang lebih besar, terutama dalam penangkapan ikan pelagis.

Masalah penggunaan lainnya adalah dalam konteks spasial, lahan-lahan tambak Desa Morodemak memiliki kualitas yang berbeda, sehingga lahan-lahan yang terbentuk akibat sedimentasi dan terabrasi, harga sewanya lebih kecil dibandingkan lahan-lahan yang terbentuk dari pembukaan hutan Mangrove.

Produksi yang menurun, lahan tambak yang marjinal disiasati dengan penanaman kembali Mangrove. Di samping itu masyarakat Desa Morodemak mulai menemukan kembali sumber daya milik bersama mereka, yaitu sungai-sungai yang selama ini diokupasi untuk permukiman, bangunan liar untuk warung, dan dibiarkan menjadi 'sungai sampah'. Pada awalnya sungai sampah ini terbentuk karena masyarakat merasakan manfaat untuk kebersihan sungai ini hanya untuk pemilik tambak, namun seiring dengan kasus malaria, akibat hilangnya lahan tambak dan genangan air di permukiman akibat saluran mampat, masyarakat mulai menyadari fungsi sungai, dan kembali menganggapnya sebagai sumber daya bersama, begitu juga 'kawasan Mangrove' yang tersisa, dijadikan ruang bersama dan dinikmati jasa lingkungannya, sebagai wilayah penyangga, tempat pembibitan, habitat burung, dan habitat kepiting lumpur, serta menjadi destinasi wisata.

Persoalan pembentukan 'sumber daya bersama' seperti yang ingin dilakukan pemerintah Pusat untuk mengatur nelayan agar menggunakan alat tangkap yang ramah lingkungan terbentur pada kondisi sosial ekonomi masyarakat, seperti dalam karakteristik 
yang diberikan Ostrom (2009) dan penelitian lanjutan yang dilakukan oleh Woodward dan Collin-Costilo (2015), Fischer (2018), Mujio et al., (2016) yang menyatakan pengaturan swakelola (self governance) dipengaruhi oleh faktor kepentingan dan keterlibatan pemangku kepentingan dalam pembuatannya, menimbang kondisi biofisik, keragaman, dan unsur ketidakpastian. Ini dapat dilihat dari penolakan masyarakat di pesisir Utara Jawa, dan bagian lain dari Indonesia terhadap aturan main yang dilakukan Kementerian Kelautan dan Perikanan untuk menggunakan alat yang ramah lingkungan, justru karena keragaman sosial ekonomi nelayan, persaingan antar nelayan yang tidak adil, ketidakpastian dalam peneguhan sanksi pelanggaran, dan adanya 'jalur ikan' di luar teritorial desa, dimana nelayan dari desa lain bisa mencegat ikan dengan alat tangkap yang tidak ramah lingkungan. ${ }^{6}$

Sebaliknya sumber daya bersama 'terbentuk' dari perubahan bentang alam dan kebutuhan membentuk kembali ruang bersama dengan penggunaan campur (mixed used) di sempadan sungai yang selama ini dikuasai privat untuk warung atau WC umum, menjadi domain publik untuk menjemur ikan, tempat bermain anak, tempat bercengkerama waktu sore dan malam hari, terjadi di desa Morodemak.

\section{KESIMPULAN}

Kondisi wilayah seperti perubahan ekologi dan populasi menyebabkan masyarakat membentuk kembali aturan main, termasuk di dalamnya yaitu pembatasan terhadap penggunaan sumber daya bersama yang mereka miliki lewat teknologi (alat tangkap) seperti di Desa Morodemak dan strategi teritorialisasi (penandaan geografis) di Desa Kawa. Hal ini dimaksudkan untuk tetap bertahan dan sebagai strategi keberlangsungan penghidupan berkelanjutan.

Konsep sumber daya bersama bisa dibentuk ulang seperti kasus Morodemak dalam pengaturan sempadan sungai. Pembentukkan

${ }^{6}$ Nelayan-nelayan dari Tegal dan Indramayu menurut nelayan Morodemak paling sering melanggar batas sumber daya bersama yang relatif baru ini didasarkan oleh perubahan ekologi yang merugikan seluruh masyarakat sebagai kesatuan sosial. Kesadaran ini terbentuk lebih sebagai respon atas permasalahan yang mereka hadapi bersama.

\section{SARAN}

Pengaturan lain seperti meningkatkan kualitas ruang publik sebagai media interaksi dibutuhkan untuk memperkuat modal sosial, terutama di daerah pasca konflik. Ruang publik di Desa Kawa ada di masing-masing dusun, namun ruang publik bersama ada pada aktivitas sehari-hari dalam interaksi di kebun dan pasar. Kekhawatiran mengenai tersingkirnya Orang Adat dalam berbagai aktivitas ekonomi dapat dimediasi oleh pengaturan di pasar, termasuk mempertahankan sistem pertukaran tradisional jika masih berlaku. Hal ini seperti yang disarankan dalam Scoones (1998) bahwa intervensi dalam berbagai institusi formal dan non formal perlu dipelajari untuk mengembangkan strategi penghidupan yang berkelanjutan.

Sedangkan di Desa Morodemak penguatan modal sosial dalam ruang publik mestinya lebih banyak dilakukan di sempadan sungai yang tersisa sebagai mixed use area ketika persoalan-persoalan sehari-hari dapat dibicarakan dan konflik dapat dimediasi secara cepat karena informasi dapat lebih terbuka dan menjangkau banyak orang.

\section{TERIMAKASIH DAN PENGHARGAAN}

Penulis mengucapkan terimakasih kepada kolega di Pusat Pengkajian Perencanaan Pembangunan Wilayah (P4W) Institut Pertanian Bogor, Dr. Siti Nurisjah, Dr. Candraningratri Ekaputri Widodo, Galuh Syahbana Indraprahasta, Ray March Syahadat, Priambudi Tri Putra, Reza Setia Raharja Putra, yang telah berbagi catatan dan berdiskusi dalam tulisan

teritorial pesisir Morodemak dan menghabiskan ikan dengan alat tangkap pukat yang kini dilarang. 
yang sebagian merupakan hasil dari penelitian tentang permukiman nelayan, Sekaya Maritim.

\section{DAFTAR PUSTAKA}

Adhuri, D. S, Rachmawati, L., Sofyanto, H. \& Hamilton-Hart, N. (2016). Green market for small people: Markets and opportunities for upgrading in small-scale fisheries in Indonesia. Marine Policy 63(2016), 198-205

Alland Jr, A. (1975). Adaptation. Annual Review of Anthropology 4(1975), 59-73.

Ashley, C. \& Carney, D. (1999). Sustainable Livelihoods: Lessons from Early Experience. London: DFID

Colin-Castillo, S. \& Woodward, R. T. (2015). Measuring the potential for selfgovernance: an approach for the community-based management of the common-pool resources. International Journal of the Commons 9(1), 281-305

DFID. (2001). DFID Sustainable Livelihoods Guidance Sheets. www.ennonline.net/ dfidsustainableliving

Ellis, F. (2000). Rural Livelihoods and Diversity in Developing Countries. Oxford: Oxford University Press

Fabinyi, M. (2018). Environmental fixes and historical trajectories of marine resource use in Southeast Asia. Geoforum 91 (2018), 87-96

Fischer, A. P. (2018). Pathways of adaptation to external stressors in coastal naturalresource-dependent communities: Implications for climate change. World Development, in press

Hardesty, D. L. (1977). Ecological Anthropology. New York: Mc Graw-Hill.

Harvey, D. (1989). The Condition of Postmodernity. London: SAGE Publications Ltd.

Harvey, D. 2010. Imperialisme Baru: Geneologi dan Logika Kapitalisme Kontemporer. Yogyakarta: Resist Book
Haryono, T. J. S. (2005). Strategi Kelangsungan Hidup Nelayan: Studi tentang diversifikasi pekerjaan keluarga nelayan sebagai salah satu strategi dalam mempertahankan kelangsungan hidup Berkala Ilmiah Kependudukan. 7(2), 119128

Kanas, A., Scheepers, P. \& Sterkens, C. (2017). Positive and negative contact and attitudes towards the religious out-group: Testing the contact hypothesis in conflict and nonconflict regions of Indonesia and the Philippines. Social Science Research 63 (2017), 95-110

Kementerian Perikanan dan Kelautan RI. (2016). Laporan Akhir Penyusunan Data Dasar Program Sekaya Maritim dan Pengembangan Model Permukiman di 10 Lokasi Prioritas

Kusnadi. (2009). Keberdayaan Nelayan dan Dinamika Ekonomi Pesisir. Yogyakarta: Arruz Media

Kusnadi. (2000). Nelayan: Strategi Adaptasi dan Jaringan Sosial. Bandung: Humaniora Utama Press

McCarthy, J. J., Canziani, O. F., Leary, N. A., Dokken, D. J., \& White, K. S. (Eds.). (2001). Climate Change 2001: Impacts, Adaptation, and Vulnerability. Cambridge: Cambridge University Press

Magis, K. (2010). Community resilience: an indicator of social sustainability. Society \& Natural Resources 23(5), 401-416

Mujio, Adrianto, L., Soewardi, K. \& Wardiatno, Y. (2016). Analisis potensi konflik pemanfaatan ruang kawasan pesisir: integrasi rencana tata ruang darat dan perairan pesisir. Sodality: Jurnal Sosiologi Pedesaan, Agustus (2016), 139144.

Nurcahyanti, E. E., Surjono, \& Kurniawan, E. B. (2010). Penataan Permukiman Nelayan Puger Ditinjau Dari Aspek Kekumuhan dalam Jurnal Tata Kota dan Daerah, 2(2), 41-48. 
Ostrom, E., Gardner, R., \& Walker, J. (1994). Rules, Games, and Common-Pool Resources. The University of Michigan Press

Ostrom, E. (2009). A general framework for analyzing sustainability of social ecological systems. Science 325(5939), 419-422

Sahlins, M. D. (1968). Culture and Environment: The Study of Cultural Ecology. Theory in Anthropology A Sourcebook. R. Manners \& D. Kaplan (Eds.) Chicago: Aldine.

Setiawan, W. \& Barrett, P. S. (2016). The built environment element of economic development in post conflict response in Indonesia. Procedia - Social and Behavioral Sciences 234 (2016), 478-487

Scoones, I. (1998). Sustainable Rural Liveihoods A Framework for Analysis. IDS Working Paper 72. Institute of Development Studies

Wakano, A. (2009). Dampak konflik Maluku: studi konflik dan kekisruhan pada pengungsi Iha, Kayu Tiga dan, Seriholo. Agama dan Pergeseran Representasi : Konflik dan Rekonsiliasi di Indonesia. Jakarta: Penerbit Wahid Institute 